\title{
Perspectives on the Transition From Bacterial Phytopathogen Genomics Studies to Applications Enhancing Disease Management: From Promise to Practice
}

\author{
George W. Sundin, Nian Wang, Amy O. Charkowski, Luisa F. Castiblanco, Hongge Jia, and Youfu Zhao
}

\begin{abstract}
First and fourth authors: Department of Plant, Soil, and Microbial Sciences, Michigan State University, East Lansing; second and fifth authors: Citrus Research and Education Center, Department of Microbiology and Cell Science, Institute of Food and Agricultural Science, University of Florida, Lake Alfred; third author: Department of Plant Pathology, University of Wisconsin-Madison; sixth author: Department of Crop Sciences, University of Illinois at Urbana-Champaign.
\end{abstract}

Accepted for publication 5 May 2016.

\begin{abstract}
Sundin, G. W., Wang, N., Charkowski, A. O., Castiblanco, L. F., Jia, H., and Zhao, Y. 2016. Perspectives on the transition from bacterial phytopathogen genomics studies to applications enhancing disease management: From promise to practice. Phytopathology 106:1071-1082.

The advent of genomics has advanced science into a new era, providing a plethora of "toys" for researchers in many related and disparate fields. Genomics has also spawned many new fields, including proteomics and metabolomics, furthering our ability to gain a more comprehensive view of individual organisms and of interacting organisms. Genomic information of both bacterial pathogens and their hosts has provided the critical starting point in understanding the molecular bases of how pathogens disrupt host cells to cause disease. In addition, knowledge of the complete genome sequence of the pathogen provides a potentially broad slate of targets for the development of novel virulence inhibitors that are desperately needed for disease management. Regarding plant bacterial pathogens and disease management, the potential for utilizing genomics resources in the development of durable resistance is enhanced because of developing technologies that enable targeted modification of the host. Here, we summarize the role of genomics studies in furthering efforts to manage bacterial plant diseases and highlight novel genomics-enabled strategies heading down this path.
\end{abstract}

Genome-enabled studies have led us to a fabulous new era of biology, allowing the testing of long-standing hypotheses and the generation of new ones. In recent years, genome-enabled approaches have deepened our understanding of phytopathogen evolution and virulence, of disease resistance, and of population biology. Some of these fundamental discoveries led to the development of important new tools that have had a wide-ranging impact on biology and medicine. Genomics has also been used in applied studies, has sped the development of pathogen detection methods, and has improved our knowledge of the details of disease epidemiology.

Management of bacterial diseases of plants has lagged behind management of diseases caused by viruses, fungi, oomycetes, and nematodes, because we lack effective chemicals to control these diseases. In many cases, we also lack effective plant resistance and, for some bacterial diseases, we lack a fundamental understanding of

Corresponding author: G. W. Sundin; E-mail address: sundin@msu.edu

http://dx.doi.org/10.1094/PHYTO-03-16-0117-FI

(C) 2016 The American Phytopathological Society plant disease-resistance mechanisms. In contrast, our understanding of how bacteria infect plants, particularly our understanding of a few model systems, is more advanced for bacterial pathogens than for other plant pathogens, and genome-enabled studies have provided even deeper insights into molecular mechanisms and the evolution of disease. Genome-enabled approaches have just begun to impact management of bacterial diseases, and many exciting possibilities are on the horizon.

For decades, phytobacteriologists have written into almost every grant proposal that elucidation of virulence mechanisms of plantpathogenic bacteria would lead to enhanced disease control. Has this proven true and have genome-enabled studies sped our progress in management of bacterial diseases? Our objective in this perspectives article is not to exhaustively recount and analyze the contributions of genomics to our knowledge of bacterial pathogenesis and host-plant interactions. Instead, we aim to summarize the role of genomics studies in furthering efforts to manage bacterial plant diseases and highlight novel genomics-enabled strategies heading down this path.

A brief history of genomic analyses of bacterial plant pathogens. In the 1990s, there was a massive effort to sequence the model bacterium Escherichia coli by Sanger sequencing (Blattner et al. 
1997), but this was overtaken by the improved high-throughput technology and genome assembly used to sequence Helicobacter pylori (Tomb et al. 1997). At this time, genome sequencing was still expensive, with grants for single genome sequences requiring \$1 million in funding or more. The success in quickly sequencing the $H$. pylori genome combined with the high price tag per genome caused intense discussions among plant pathologists on which single plant-pathogenic bacterium should be sequenced first. The discussions were useful in crystallizing why particular models were favored but, because genome sequencing technologies improved so quickly, these discussions fell by the wayside, and individual lab groups simply began sequencing genomes. By 2000, the first genome of a plant-pathogenic bacterium, Xylella fastidiosa, was published (Simpson et al. 2000). By 2016, genomes of all of the major bacterial plant pathogens have been sequenced, either fully or in draft form, and draft bacterial genomes cost, at most, a few hundred dollars to obtain. Genomics has changed how we study plant pathogens, as evidenced by the increase in the use of the words "genome" and "genomic" in abstracts submitted to the American Phytopathological Society annual meeting (Fig. 1). Other 'omics' terms, however, such as proteomic and metabolomic, are still not widely used, suggesting that plant pathology lags in these areas.

Can we better explain pathogenicity with genomic data? The Pseudomonas syringae type III secretion system (T3SS) effector example. Genomics has had the largest immediate impact on model systems because plant pathologists already had a significant base of knowledge upon which to build. The use of genomics to identify the complete effector repertoire from several gram-negative bacterial plant pathogens is a clear example of this.

Many gram-negative bacterial plant pathogens use the T3SS to inhibit plant defenses and promote virulence. This specialized secretion system translocates virulence proteins, termed effectors, into the cytoplasm of plant host cells via a needle-like appendage that connects the bacterial and plant cell cytoplasms (Galán and Collmer 1999). Effectors sometimes elicit plant defense responses, and this avirulence effect led to the discovery of the first effector, AvrB (Staskawicz et al. 1984). Efficient effector discovery was stalled, however, until the advent of genomics because T3SS effectors within a cell lack homology, they lack easily monitored activities in the absence of plant resistance genes, and their redundancy and partially overlapping roles in virulence means that mutagenesis of individual effectors has, at most, minor effects on virulence. Often, deleting individual effectors from a bacterial genome has no measurable alteration on bacterial virulence. Therefore, standard genetic approaches to virulence gene discovery were ineffective.

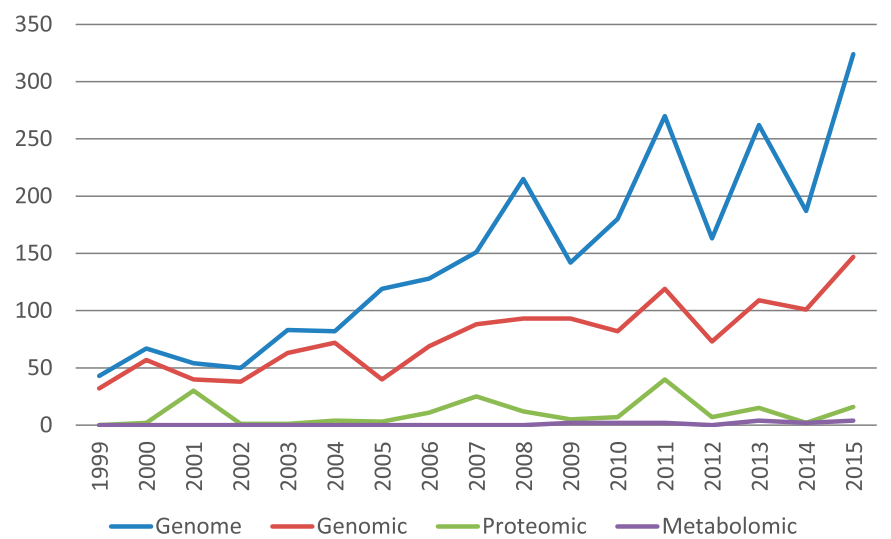

\section{FIGURE 1}

Number of abstracts submitted to The American Phytopathological Society annual meeting (1999 to 2015) with the words "genome," "genomic," "proteomic," or "metabolomic" in the title or body of the abstract.
Sanger sequencing of cosmid clones from the model plantpathogen Pseudomonas syringae, combined with the knowledge that the T3SS structural genes and genes encoding T3SS effectors comprise a regulon under the transcriptional regulatory control of an alternate sigma factor, HrpL (Xiao and Hutcheson 1994), led to discovery of numerous effectors encoded adjacent to the T3SS gene cluster (Alfano et al. 2000). These data, combined with genome sequences and functional studies, aided in development of hidden Markov models based on the HrpL binding site that identified putative effectors genome wide in P. syringae (Fouts et al. 2002). Together with functional approaches based on fusion of putative effector genes to a reporter based on a known effector gene, Chang et al. (2005) identified a comprehensive effector repertoire from two $P$. syringae strains just two years after publication of the first P. syringae genome (Buell et al. 2003).

Despite access to the entire effector repertoire, it was still not clear how the majority of these proteins promoted virulence (Cunnac et al. 2009) and it also appeared that $P$. syringae strains have taken different evolutionary paths, even on shared hosts (Lindeberg et al. 2009). The P. syringae literature in recent years is filled with step-by-step analyses of the role of individual effectors in $P$. syringae virulence, and genomics-enabled methods allow each individual protein to be placed within a larger systems view of pathogenesis (Chung et al. 2014; Gimenez-Ibanez et al. 2014; Wei et al. 2015). Genomics-enabled methods also allow discoveries on how the T3SS is coordinated with other important virulence factors (Mucyn et al. 2014), the basis for host range and host specialization (Baltrus et al. 2012), the basis for high and low virulence within the same species (McCann et al. 2013), and global views of plant pathways targeted by effectors (Mukhtar et al. 2011).

These detailed and elegant discoveries have changed our view of plant pathogenesis far beyond $P$. syringae, but they have not yet been translated to improved food, fiber, and fuel production, in large part because genetically modified plants designed to resist disease are not yet widely accepted by the public for most crops. This will change and change swiftly, however, with novel technologies that allow precise genomic modifications. For example, Kim et al. (2016) recently modified the cleavage site in the Arabidopsis protein PBS1 so that it is cleaved by a viral protease from Tobacco etch virus, thereby converting a bacterial resistance gene into a viral resistance gene. Amazingly, one of the novel genome modification tools that can be used to construct resistant plants was discovered through work with T3SS effector proteins.

Unexpected benefits of basic research in T3SS effectorsTALEN (transcription activator-like effector nuclease) biotechnology. There are two categories of T3SS systems in plant-pathogenic bacteria, one represented by homologous systems encoded by $P$. syringae and the plant pathogens in the Enterobacteriaceae and the other by Xanthomonas and Ralstonia species (Alfano and Collmer 1997). The effectors secreted by these systems and the role they play in bacterial virulence also differ, with none more representative of this than the TAL effectors of Xanthomonas campestris.

TAL effectors were immediately recognized as remarkable because of the high number of direct repeats they encode (Bonas et al. 1989). The function of these repeats was discovered independently in the same year by two groups who took advantage of similar genome-informed approaches (Boch et al. 2009; Moscou and Bogdanove 2009). Each TAL effector repeat binds to a nucleic acid in a promoter and the binding site can be predicted by examining the variable region of each repeat. Unlike $P$. syrinage effectors, which act on proteins in the host cytoplasm, membrane, or nonnuclear organelles, Xanthomonas TAL effectors are transcription factors targeted to the host cell nucleus. In the plant nucleus, TAL effectors activate otherwise quiescent genes, such as sugar exporters (SWEET proteins) that are presumed to favor bacterial virulence (Doyle et al. 2013). In some cases, TAL effectors have been shown to activate expression of a gene conferring host resistance (executor 
$R$ genes) (Doyle et al. 2013). Resistant plants can be constructed simply by altering the TAL effector binding site in front of a susceptibility gene or by adding binding sites for specific TAL effectors in front of an executor $R$ gene (Doyle et al. 2013).

The amazing part of this bit of science history is that the resistant plants can be constructed with technology based on the TAL effectors. The repeat region of TAL effectors can be modified to bind specific DNA targets and fusions of TAL repeats with nuclease enzymes allow design of nucleases with high specificity to target DNA sequences (Cermak et al. 2011). This engineering feat led quickly to development of disease-resistant rice constructed with tools based on a virulence gene of a rice pathogen ( $\mathrm{Li}$ et al. 2012) and also to numerous other uses in plant biotechnology and human medicine. The TAL effector story quickly became another classic example of the high but unpredictable value that basic research can bring. When AvrBs3 was first described by Bonas and colleagues in 1989 , no one could have guessed that studying this curious protein would lead to gene therapies for a wide range of human diseases (Poirot et al. 2015; Ramalingam et al. 2014).

Global virulence gene discovery through regulon delineation. The regulation of virulence in plant-pathogenic bacteria can be complex, as some pathogens dwell in distinct habitats in addition to their plant hosts and others express different sets of virulence genes based on location within the host. As with most traits in bacteria, virulence genes are tightly regulated, typically at the transcriptional and posttranscriptional level. Transcriptional regulation via alternate sigma factors, two-component signal-transduction (TCST) systems, and quorum sensing are common in plant-pathogenic proteobacteria, and these regulatory factors are commonly applied to genomics studies of bacterial pathogenesis. For example, the identification of "hrp box" sequence elements in promoter regions of T3SS genes regulated by the HrpL alternate sigma factor was one of the first bioinformatic studies done following the availability of genome sequences in $P$. syringae (Zwiesler-Vollick et al. 2002), and this information aided in later global discovery of effectors.

Genome-enabled global identification, mutation, and analysis of virulence effects of TCST genes has been conducted in Xanthomonas campestris pv. campestris and in Erwinia amylovora (Qian et al. 2008; Zhao et al. 2009), and quorum-sensing regulons have been intensively studied in pathogens such as Xanthomonas campestris and Xylella fastidiosa (Ryan et al. 2015) and in Pectobacterium spp. (Liu et al. 2008). These studies provide comprehensive catalogs of genes in each regulon studied, but they do not provide much insight into the time dimension of gene regulation, the molecular conversation that occurs between pathogen and host, nor do they show how these various regulons are coordinated during pathogenesis. Improved software tools, hopefully with dynamic game-like interfaces, and focused host pathogen interaction studies are required to gain a comprehensive and intuitive sense of phytopathogen gene regulation during infection.

More recently, new virulence regulators such as the second messenger compound cyclic diguanylate monophosphate (c-di-GMP), (p)ppGpp, and small RNA (sRNA) posttranscriptional regulators have been identified as virulence regulatory players in clinical bacterial pathogens and environmental biofilm-forming bacteria. Comparative genome sequencing has been frequently utilized to identify proteins with domains potentially involved in c-di-GMP synthesis (GGDEF) and degradation (EAL and HD-GYP). These two enzymatic systems work in coordination to maintain levels of c-di-GMP necessary for regulatory function (Romling et al. 2013). Regarding bacterial virulence, elevated c-di-GMP levels typically induce exopolysaccharide synthesis, including cellulose synthesis and biofilm formation, and decreased c-di-GMP levels are required for expression of the T3SS (Ham 2013; Romling et al. 2013). Analysis of the involvement of c-di-GMP in regulating virulence in plant pathogens was first studied extensively in Xanthomonas campestris pv. campestris, in which c-di-GMP and quorum sensing are integrated in regulating extracellular enzyme and exopolysaccharide synthesis and biofilm formation (Dow et al. 2006). c-di-GMP signaling typically acts through proteins containing c-di-GMPbinding domains such as the PilZ domain (Chou and Galperin 2016). The role of c-di-GMP in regulating virulence in plant pathogens is a fast-moving field that has been reviewed recently (Ham 2013); additional recent findings are summarized in Table 1. In a similar manner, guanosine tetraphosphate (ppGpp) acts as an internal signaling molecule and is used by E. amylovora and $P$. syringae to sense conditions of nutrient limitation and stimulate expression of the T3SS (Ancona et al. 2015; Chatnaparat et al. 2015). Both c-di-GMP and ppGpp represent potential targets for attack by small inhibitory molecules in disease intervention strategies (Sambanthamoorthy et al. 2012).

A wave of bioinformatic and transcriptomic studies performed during the last several years have identified sRNAs in bacterial plant pathogens and have shown the involvement of these regulators in pathogenesis. The first bacterial sRNA shown to be involved in plant-pathogen interactions was RsmB, a sRNA molecule that, in combination with the regulatory protein RsmA, modulated the production of extracellular enzymes and the T3SS in Pectobacterium carotovorum (Liu et al. 1998). The RsmB::RsmA system is also regulated by the global regulator GacA in several plantpathogen genera including the enterobacterial pathogens and $P$. syringae (Lapouge et al. 2008), and critical virulence regulatory functions have been demonstrated in enteric genera including Dickeya and Pectobacterium (Table 2). Other regulatory effects of sRNAs are at the posttranscriptional level, in which an individual sRNA molecule will most typically bind with a cognate messenger RNA and either activate or inhibit translation (Waters and Storz 2009). With the advent of transcriptomic analyses and specialized RNA genome sequencing techniques that selectively sequence sRNA species, these molecules have been analyzed on a global level in genera such as Agrobacterium and Xanthomonas (Abendroth et al. 2014; Wilms et al. 2012). Many sRNAs also rely on chaperone protein $\mathrm{Hfq}$ for stability and for assistance in locating and binding to target sequences in the host (Vogel and Luisi 2011). Specific sRNAs with important roles in virulence have been identified in several plant pathogen genera over the past several years (Table 2), and the integration of sRNA and c-di-GMP pathways in virulence regulation are beginning to be uncovered (Yuan et al. 2015).

Virulence gene discovery in recalcitrant plant pathogensNetflix for phytopathogens. The impressive genomics-enabled advances in effector biology in genera Pseudomonas and Xanthomonas are based on decades of functional studies from a relatively large and active worldwide research community. The research communities that focus on more recalcitrant plant pathogens, such as nonculturable microbes (e.g., Liberibacter spp.) or relatively difficult-to-manipulate phytopathogens (essentially all gram-positive plant pathogens), also benefit from genome sequences.

Prior to the availability of genome sequences, it was a struggle to gain an understanding of mechanisms of pathogenesis in these organisms. In the case of the nonculturable pathogens and putative causal agents of huanglongbing disease of citrus and zebra chip disease of potato, genome sequencing was necessary just to give researchers a starting point in an attempt to characterize the putative causal agents and understand how these organisms cause disease (Duan et al. 2009; Lin et al. 2011).

In the gram-positive pathogen Clavibacter michiganensis subsp. michiganensis, an organism in which global mutagenesis systems are not readily available, genome sequencing enabled the identification of several chromosomal regions with lower percent $\mathrm{G}+\mathrm{C}$ content than the rest of the genome that contained putative virulence genes (Gartemann et al. 2008). Comparative genome analyses also identified similar genes in widespread pathogens, which aids in developing cross-cutting themes for bacterial pathogenesis of plants. For example, plant cell wall-degrading enzymes and the coronatine-like phytotoxins are encoded by both the gram-negative 
soft rot and blackleg pathogen Pectobacterium atrosepticum (Bell et al. 2004) and are the gram-positive cause of common scab Streptomyces scabies (Bignell et al. 2010), suggesting that these homologous horizontally acquired virulence factors can improve fitness of disparate plant pathogens.

The problem with genome-enabled analysis of recalcitrant pathogens is that, as with coronatine-like toxins in S. scabies, it relies almost entirely on homology with known virulence genes, which is itself reliant almost entirely on an arbitrary set of sequenced genomes. Ma et al. (2014) addressed this by developing a supervised machine-learning program that uses a wide range of genomic data to rank all genes in a genome for their probability of playing a role in plant-microbe interactions. They took this approach with plantpathogenic Enterobacteriaceae species, which are easily manipulated, because there is more genomic information for this family than any other family of bacteria. The output of this program is currently being tested, with the hope that this approach will be useful for more challenging pathogens. The plant-pathology community still needs to invest in functional studies in these difficult pathogens and in novel bioinformatics and modeling methods, such as that described in Ma et al. (2014), to make substantial progress in working with most bacterial plant pathogens.

Comparative genomic analyses significantly improve the specificity of pathogen detection. Comparative genomics has become a very valuable tool for highly specific pathogen detection. This methodology has become more and more important as we identify and learn about very genetically closely related pathogens that cause distinct diseases. The availability of genome sequences has taken the search for sequences specific to individual species or intraspecies groups to the next level. For example, four complete and 16 draft genome sequences of Dickeya spp. were used to fuel a computer pipeline to generate diagnostic primer sets for $D$. dianthicola and for the emerging pathogen D. solani (Pritchard et al. 2013).

A similar computational genomics pipeline aligned known sequenced genomes of Xanthomonas spp., ultimately identifying primer sets usable for detection of $X$. oryzae pv. oryzae and $X$. oryzae pv. oryzicola (Lang et al. 2010) and for highly virulent $P$. syringae strains (Jones et al. 2015). The rapid and accurate detection of quarantine pathogens is a critical component of phytosanitary measures. Loopmediated isothermal amplification (LAMP) protocols for plant pathogen detection amplify DNA with high specificity and rapidity under isothermal conditions. LAMP protocols also offer the advantage of portability and are tolerant to high levels of contaminants (Kaneko et al. 2007) and, thus, can be conducted under field conditions. Examples of genome-enabled primer selection for LAMP protocols of plant pathogens include the detection of the citrus huanglongbing pathogen 'Candidatus Liberibacter asiaticus' (Rigano et al. 2014), E. amylovora (Bühlmann et al. 2013), and Ralstonia solanacearum (Kubota et al. 2011).

Importantly, these methods do not negate the absolute need to validate these primer sets, however. In practice, primer sets developed using comparative genomics still often fail when validated for either specificity or sensitivity. This is likely because primer design algorithms still do not accurately model DNA-binding interactions and they do not include metagenomics data from soil or plants that may include common competing sequences. Therefore, improvements are still necessary before genomics-enabled design can begin to replace rigorous validation of diagnostic primer sets.

TABLE 1

Recent examples of cyclic diguanylate monophosphate (c-di-GMP) signaling modulating virulence in plant-pathogenic bacteria

\begin{tabular}{llc}
\hline Organism & \multicolumn{1}{c}{$\begin{array}{c}\text { Virulence phenotypes regulated } \\
\text { by c-di-GMP }\end{array}$} & Reference \\
\hline Agrobacterium tumefaciens & Regulation of attachment and biofilm formation & Feirer et al. 2015 \\
\hline Dickeya dadantii & $\begin{array}{c}\text { EcpC, phosphodiesterase and major regulator of the type III } \\
\text { secretion system (T3SS) }\end{array}$ & Yuan et al. 2015 \\
\hline Erwinia amylovora & $\begin{array}{c}\text { Five GGDEF and EAL domain proteins regulate motility, EPS } \\
\text { production, biofilm formation, T3SS, and virulence }\end{array}$ & Edmunds et al. 2013 \\
\hline Pectobacterium atrosepticum & Regulation of secreted cellulases, pectinases, and proteases & Tan et al. 2014 \\
\hline $\begin{array}{l}\text { Pseudomonas savastanoi pv. } \\
\text { savastanoi }\end{array}$ & BifA, regulator of motility, biofilm formation, and virulence & Aragón et al. 2015 \\
\hline Xanthomonas oryzae ov. oryzae & $\begin{array}{c}\text { PXO_00049 and PXO_02374 negatively regulate the T3SS } \\
\text { PXO_00403, c-di-GMP receptor required for full virulence }\end{array}$ & $\begin{array}{c}\text { Yang et al. 2015 } \\
\text { Yang et al. 2014b }\end{array}$ \\
\hline Xylella fastidiosa & $\begin{array}{l}\text { CgsA, regulator of biofilm formation, virulence, and insect } \\
\text { vector transmission }\end{array}$ & Chatterjee et al. 2010 \\
Eal, regulator of motility, biofilm formation, and Virulence & de Souza et al. 2013 \\
\hline
\end{tabular}

TABLE 2

Examples of small RNAs modulating virulence in plant-pathogenic bacteria

\begin{tabular}{llll}
\hline Organism & \multicolumn{1}{c}{ sRNA } & Virulence phenotypes regulated & Reference \\
\hline Agrobacterium tumefaciens & RNA1111 & Significant increase in virulence in $\Delta r n a 1111$ mutant & Dequivre et al. 2015 \\
\hline Dickeya dadantii & RsmB & Type III secretion system (T3SS) & Yang et al. 2008 \\
\hline Erwinia amylovora & ArcZ & T3SS, amylovoran production, motility & Zeng and Sundin 2014 \\
& Hrs6, OmrAB & Amylovoran production, motility & Zeng and Sundin 2014 \\
& RprA & Significant decrease in virulence in $\Delta r p r A$ mutant & Zeng et al. 2013 \\
\hline Pectobacterium carotovorum & RsmB & T3SS & Liu et al. 1998 \\
\hline Xanthomonas campestris pv. & sX12 & Loss of virulence and reduced HR in $\Delta$ sX12 & Schmidtke et al. 2012 \\
vesicatoria & sX13 & Delayed symptoms, reduced HR in $\Delta$ SX13 & Schmidtke et al. 2013 \\
\hline
\end{tabular}


Currently, pathogen detection strategies aim to identify bacterial pathogens in seed lots, soil, irrigation water, or in diseased plants in the field. Once identified, the seed lot may be discarded, the field may not be planted with a particular crop, or the farmer may make different plans for subsequent years to avoid future losses. However, we do not yet have sophisticated enough management strategies to respond to the detailed information possible to obtain with genomeenabled detection methods. Should significant advances be made with biocontrol, and particularly with phage-based management of bacterial diseases, farmers may someday be able to choose a targeted treatment for a field or seed lot based on the genome of the pathogens present in that lot.

Plant genome modification and generation of disease-resistant plants. Plant resistance to bacterial pathogens is the most effective and efficient disease management method. Have genome-enabled studies improved our ability to breed or develop resistant plants?

Advances in the sequencing of plant genomes have significantly promoted targeted genome engineering in the identification of suitable target sites and analysis of off-targets in generating diseaseresistant plants. Consumer acceptance, trade barriers, and challenging regulatory requirements remain major limitations to use of these technologies in plant disease management. Federal, state, and grower funding for public plant breeders to navigate the path from plant development to consumer acceptance is extremely limited, so public development of modified plants for commercial use is essentially stalled for many crops. This is unfortunate, because there is a strong history of public development of useful fruit, vegetable, and field crops, and this benefited consumers, farmers, and students. If the United States government and universities believe that genome modification is appropriate for crop breeding, then it should be supported through to commercial release, just like other breeding efforts. Novel methods for genome editing will change the landscape here, since changes to the plant genome will be more accurate, more subtle, and more difficult to detect.

Genome editing technologies are based on zinc finger nucleases (ZFNs), TALENs, or clustered regulatory interspaced short palindromic repeat (CRISPR)/Cas9/single guide RNA (sgRNA) (hereafter named Cas9/sgRNA). For ZFNs, the FokI nuclease domain is fused to a set of customized zinc finger proteins to cleave the targeted DNA site, which is subsequently subjected to error-prone nonhomologous end joining, leading to targeted genome editing (Urnov et al. 2010). ZFNs (Fig. 2A) have been used to modify different cells and organisms in plants, for example, apple and fig (Peer et al. 2015), soybean (Curtin et al. 2013), Arabidopsis thaliana (Lloyd et al. 2005; Zhang et al. 2010), Zea mays (Shukla et al. 2009), and tobacco (Townsend et al. 2009).

Like ZFNs, TALENs (Fig. 2B) are generated by fusing the FokI nuclease element to a TALE DNA-binding domain (Wright et al. 2014). Compared with ZFNs, TALEN technology has a more tractable feature to target the desired sequence (Chen and Gao 2013) because the repeat-variable di-residue within a conserved repeat of a TALE can specifically bind to a corresponding nucleotide (Boch et al. 2009; Moscou and Bogdanove 2009). TALENs have been used to modify many plant organisms, including Arabidopsis thaliana (Cermak et al. 2011), rice (Li et al. 2012), and Nicotiana tabacum (Zhang et al. 2013).

Unlike ZFNs and TALEN, the Cas9/sgRNA system (Fig. 2C) is not fused to the FokI nuclease element; instead, its recognition of the target sequence is based on the sgRNA, and the Cas9 protein cleaves the target sequence. The CRISPR/Cas system serves as an adaptive immune system of prokaryotes against invading phages and plasmids by cleaving the foreign DNA in a sequence-dependent manner (Barrangou et al. 2007; Jinek et al. 2012). The CRISPR locus contains a characteristic array of repetitive sequence interspaced by spacer sequences, derived from foreign genetic elements, which match the target site among the invading DNA for the specific nucleic acid cleavage mediated by CRISPR/Cas units (Wiedenheft et al. 2012). The commonly used Cas9/sgRNA is based on the type II CRISPR/Cas system from Streptococcus pyogenes SF370 (Cong et al. 2013; Mali et al. 2013), composed of Cas9, Cas1, Cas2, and Csn1, as well as CRISPR RNA (crRNA) and transactivating crRNA (tracrRNA). The type II system requires only a single protein, Cas9, for RNA-guided DNA recognition and cleavage (Jinek et al. 2012), whereas the type I and type III systems use a large complex of Cas proteins for crRNA-guided targeting, which led to the selection of Cas9 for genome editing.

In response to invading phages and plasmids, tracrRNA is transcribed and hybridizes to pre-crRNA to form functional crRNA with the aid of ribonuclease III and Cas9 protein (Deltcheva et al. 2011). Cas9 nuclease cleaves double-stranded DNA sequences known as protospacers in the invading DNA at the presence of a conserved protospacer-adjacent motif (PAM) (5'-NGG-3' or 5'-NAG-3') downstream of the target DNA (Barrangou et al. 2007; Jinek et al. 2012). The mature crRNA:tracrRNA duplex guides Cas 9 to the target protospacer region upstream of PAM, and crRNA hybridizes with the protospacer to facilitate Cas9 cleavage within protospacer. Notably, CRISPR/Cas has been simplified as a two-component Cas9/sgRNA system, which merely contains the Cas9 protein and a synthetic sgRNA containing both crRNA and tracrRNA. The engineering of the sgRNA has significantly simplified the design to program CRISPR-Cas9 to target any DNA target of interest adjacent to a PAM (Jinek et al. 2012).

Cas9/sgRNA technology is known for its simplicity and affordability and requires no changes in the Cas9 protein but only in the recombinant sgRNA for target specificity (Strau $\beta$ and Lahaye 2013), whereas both ZFNs and TALENs demand elaborate design and assembly of individual DNA-binding proteins for each DNA target (Curtin et al. 2013; Li et al. 2012; Streubel et al. 2012; Zhang et al. 2010). Cas9/sgRNA technology has been successfully used for genome editing in many plant organisms, including rice (Ma et al. 2015; Shan et al. 2014), wheat (Shan et al. 2014), sorghum (Jiang et al. 2013), tobacco (Gao et al. 2015; Jiang et al. 2013), and citrus (Jia and Wang 2014; Jia et al. 2016).

While most of the previous work on plants has focused on proofof-concept studies modifying the genome of different plants using different technologies, a few projects have led to generation of disease-resistant plants (Table 3). Although these studies do not all target bacterial pathogens, we report on the successes as clearly showing potential for the continued successful generation of engineered plants with resistance against bacterial diseases. Notable examples include the generation of bacterial blight resistant rice by modifying the effector-binding elements in the promoter of the susceptibility gene $O s 11 N 3$ via TALEN (Li et al. 2012). Cas9/sgRNA has been harnessed to modify the PthA4 effector binding elements (EBEs) in the promoter of the CsLOB1 (Citrus sinensis lateral organ boundaries) gene (Jia et al. 2016). CsLOB1 is a susceptibility gene for citrus canker, a severe disease caused by $X$. citri, and is induced by the pathogenicity factor PthA4, which binds to $\mathrm{EBE}_{\mathrm{PthA} 4}-\mathrm{CsLOBP}$ to induce CsLOB1 gene expression (Hu et al. 2014). Jia et al. (2016) successfully modified the EBE in one of the two alleles of the CsLOB1 in Duncan grapefruit. The recognition of the mutated EBE in CSLOB1 by PthA4 was significantly reduced, thus, the study has laid the foundation to develop canker-resistant citrus varieties.

Previously, disease-resistant genetically modified plants were not accepted by consumers. Many of these plants were transgenic, such as potatoes expressing bacterial lysozyme or bacterial lactonases that destroy quorum-sensing signals. Genome editing is a more elegant solution and more akin to mutations selected for in traditional breeding and, therefore, more likely to be accepted. A challenge remains, however, that for some diseases, it is not clear which genes need to be edited or inserted to improve resistance. Fortunately, genomics has also aided in improving our understanding of crops with more complex genetics, such as potato (Hamilton et al. 2011), so we are likely to gain important new tools for 
management of diseases, such as soft rot and common scab, that do not fit the paradigms developed with the leaf-infecting $P$. syringae.

Genomics-informed chemical management of bacterial diseases. Development of novel antimicrobials targeting plant bacterial pathogens. Advances in genomics and proteomics provide an unprecedented opportunity to develop antimicrobials with improved specificity against the pathogens via target-based approaches. Pharmacology represents the backbone of antibacterial research in clinical and

A

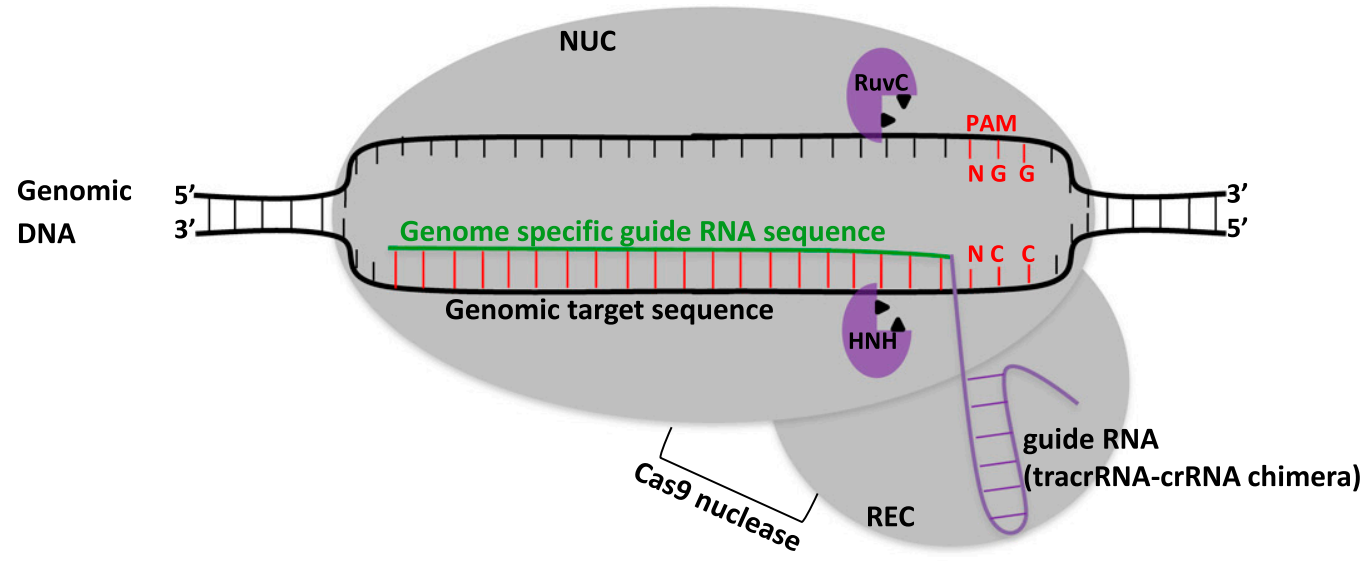

B

TALEN-L

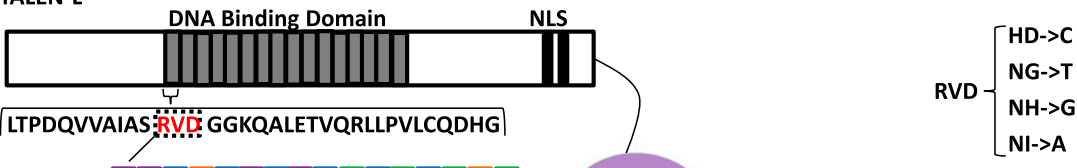

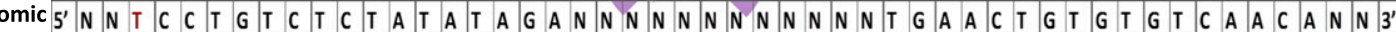

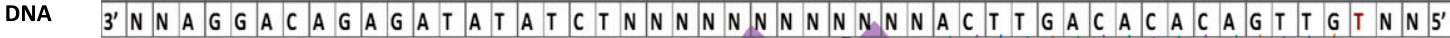
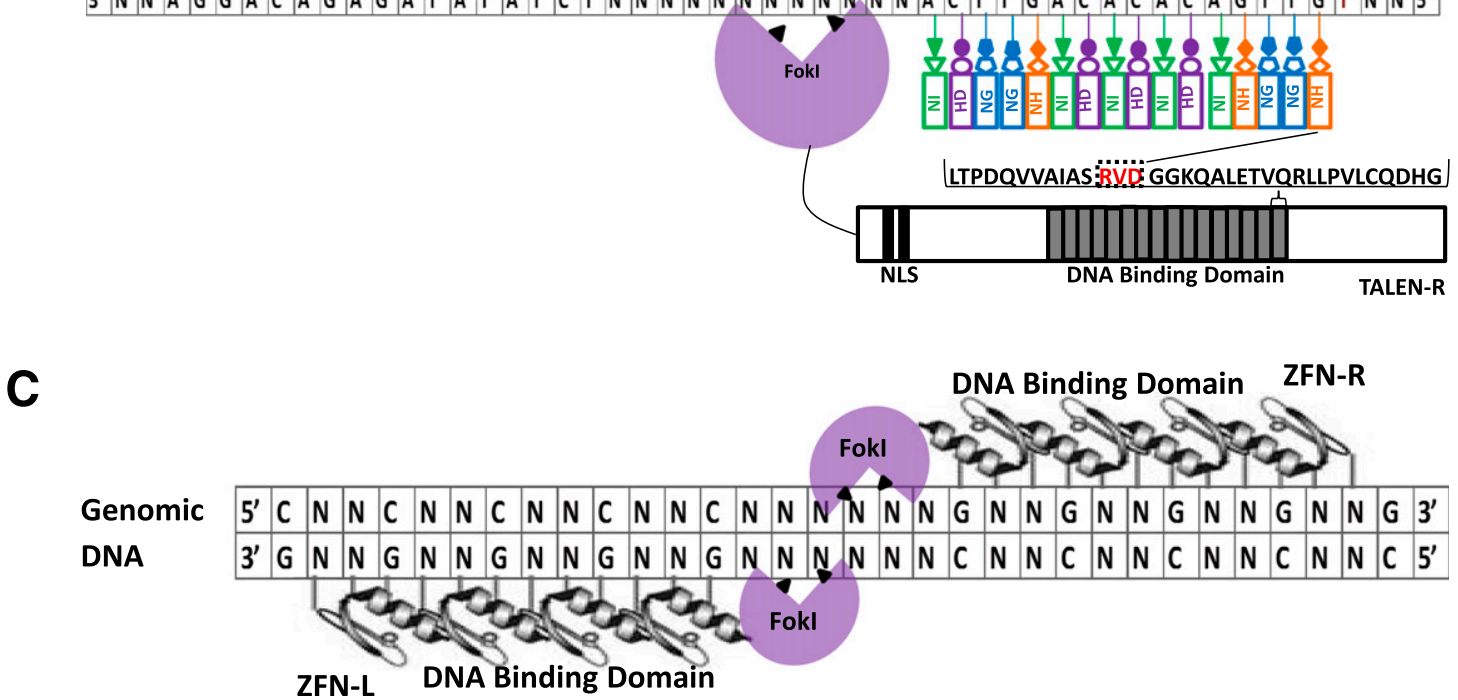

FIGURE 2

Schematic representations of clustered regulatory interspaced short palindromic repeat (CRISPR)/Cas9-, transcription activator-like effector nuclease (TALEN)-, and zinc finger nuclease (ZFN)-mediated DNA modification. A, Schematic diagram of CRISPR/Cas9-mediated DNA modification. With the aid of mature guide RNA, which is a simplified chimera of CRISPR RNA (crRNA) and transactivating CRISPR RNA (tracrRNA), Cas9 nuclease is guided to the genomic target region upstream of the protospacer-adjacent motif (PAM), leading to unzipping DNA, forming of a guide RNA (gRNA)-DNA heteroduplex, and cutting of both DNA strands, which is mediated by RuvC and HNH nuclease domains. The Cas9 recognition (REC) lobe interacts with the gRNA, whereas the nuclease (NUC) lobe drives interaction with the PAM and target sequence. Double strand breaks are usually repaired via nonhomologous end-joining, leading to insertion or deletion events or homology-directed repair, allowing the insertion or deletion of a desired DNA fragment. B, Schematic diagram of TALEN structure-mediated DNA modification. TALENs are functional as a pair, TALEN-L and TALEN-R, since the Fokl domain needs to form a dimer to cleave genomic DNA. The TALEN DNA-binding domain is a consensus repeat sequence containing the repeat-variable di-residue (RVD) that recognizes the specific nucleotide sequence. In detail, HD is for $\mathrm{C}, \mathrm{NG}$ for $\mathrm{T}, \mathrm{NH}$ for $\mathrm{G}$, and $\mathrm{NI}$ for A. Most commonly, TALEN recognizes a site preceded by T. The TALEN RVD number can range from 15 to 20, whereas the cleavage spacer has to be optimized, in responding to TALEN architectures. NLS, nuclear localization signal. C, Schematic diagram of four-finger ZFN-mediated DNA modification. Four-finger ZFN is formed by linking four monomeric ZF motifs with the Fokl nuclease domain. ZFNs function as a pair, ZFN-L and ZFN-R. In the presence of ZFN-L and ZFN-R, the two Fokl nuclease domains dimerize and cleave target DNA with the size of 5 to $7 \mathrm{bp}$. A ZFN DNA binding domain, composed of ZF motifs, naturally prefers G-rich sequences. 
animal disease systems and, even with the significant problems with antibiotic resistance in these systems, antibiotics have been tremendously successful for over 70 years in reducing mortality due to bacterial infections. Antimicrobial development and utilization in targeting plant bacterial diseases has some obvious differences from clinical and animal systems. First of all, the ability to effectively and economically deliver the antimicrobial agent within plants is not achievable at the current time. This is a significant detriment to our ability to manage critical diseases in which the pathogen is largely systemic within the host (e.g., Pierce's disease, huanglongbing) or to control soilborne pathogens such as Ralstonia solanacearum. This delivery issue means that small molecule inhibitors would need to target surface populations of bacterial plant pathogens, and this also necessitates that compounds used are not susceptible to rapid degradation in the plant surface environment. Lastly, because of current delivery methods for antimicrobials in agricultural systems, the economics of use of certain compounds may eliminate them from contention. This is because compounds that might be delivered in microgram to milligram doses in clinical situations for a single patient would have to be diluted in large volumes for use with current agricultural sprayer technology (example spray volumes in apple production are in the range of 473 to 946 liters per hectare).

Even with the lack of success in clinical research in using genomics knowledge to fuel the identification of novel druggable targets in pathogens (Brown and Wright 2016; Silver 2011), there is promise in this technology, particularly in the identification of small molecules that are inhibitory to structures necessary for pathogenesis. Small molecules are organic compounds of low molecular weight with an upper molecular weight of approximately 800 Daltons. Small molecules have been the target of pharmacology because they can bind with high affinity to proteins, nucleic acids, and polysaccharides and alter the activity or function of those biopolymers, resulting in antimicrobial or bactericidal activities (Showalter and Denny 2008). Most drug discovery begins with identifying a suitable target. Thus, the genomic revolution in genome sequencing has been the main driver of the target-based approach. The most common targets for antimicrobial agents include receptors, proteins, and enzymes, DNA, RNA, and ribosomal targets. Among them, proteins have become the major target, due to their druggable characteristics (Showalter and Denny 2008). Many potential virulence genes have served as potential targets for therapeutic intervention, including genes encoding the T3SS, Sec pathway, toxin biosynthesis, biofilms, and quorum sensing systems (Akula et al. 2011, 2012; Cegelski et al. 2008; Li and Wang 2014).

To date, a few studies have been conducted to screen antimicrobials against plant pathogens. Li et al. (2009) screened a series of plant phenolic compounds and discovered that p-coumaric acid repressed the expression of T3SS of $D$. dadantii, which causes soft-rot, wilt, and blight diseases on a wide range of plant species. They further converted p-coumaric acid into the corresponding hydroxamic acid and showed that the resulting trans-4-hydroxycinnamohydroxamic acid has improved inhibitory effect against T3SS (Li et al. 2015). Khokhani et al. (2013) screened a library of phenolic compounds and their derivatives and identified T3SS inhibitors 4-methoxy-cinnamic acid and benzoic acid against E. amylovora, which causes a devastating disease called fire blight in rosaceous plants. In addition, several compounds related to salicylidene acylhydrazides suppressed both the T3SS and amylovoran exopolysaccharide production in E. amylovora (Yang et al. 2014a). Some of these compounds represent excellent candidates for analysis of effects on disease control under field conditions.

Akula et al. $(2011,2012)$ reported the identification of antimicrobial small molecules against SecA of ' $\mathrm{Ca}$. L. asiaticus', which causes the devastating citrus huanglongbing, by structure-based design. The authors built the homology model of SecA protein structure of ' $\mathrm{Ca}$. L. asiaticus' based on the SecA of Escherichia coli. The model was used for in-silico screening of commercially available compounds from the ZINC database. Five compounds were found to inhibit the ATPase activity of SecA of ' $\mathrm{Ca}$. L. asiaticus' at nanomolar concentrations and showed antimicrobial activities against Agrobacterium tumefaciens with minimal inhibitory concentrations ranging from 128 to $256 \mu \mathrm{g} / \mathrm{ml}$. However, the antimicrobial effect of those compounds against ' $\mathrm{Ca}$. L. asiaticus' remains to be determined. Pagliai et al. (2014) also reported screening small molecules inhibiting LdtR of ' $\mathrm{Ca}$. L. asiaticus' and found that phloretin, benzbromarone, and hexestrol decreased binding of LdtR to its cognate promoters.

Summary: bacterial genomics and applications in plant disease management. Genomics and bioinformatics, functional genomics, proteomics, metabolomics, and microbiome (phytobiome) studies are all very commonly used procedures and studies conducted on bacterial plant pathogens currently. In fact, in many ways, genomics has replaced traditional hypothesis-driven science, in that genome sequence or transcriptomic data may be obtained first to lead to research questions based on that data. In the most novel work, hypotheses are built entirely on large-scale analysis of genomic data, leading to new global views of pathogenesis (Mukhtar et al. 2011). As summarized above, these studies are moving our understanding of plant bacterial pathogenesis forward. However, plant pathology, by nature, is an applied science, and the ultimate goal of the field of plant pathology is successful management of diseases. Therefore, the largest impact of genomics on plant pathology is likely to be the construction of genome-edited plants with durable resistance and the discovery of pathogen targets for chemical inhibition.

Genomics and plant bacterial disease management moving forward. The accumulation of genomic sequence data are occurring at a dizzying pace in this age of next-generation sequencing in which sequences can be obtained very easily and relatively inexpensively. What is lost in all the luster is that genomics is a descriptive science and that genomics provides us with a painting, a truly marvelous painting indeed, but a painting nonetheless. Obtaining a genome sequence can be equated to purchasing a painting. Obtaining genome sequence data does not require the artistic talent of conceptualization and creation that forms the basis of an

TABLE 3

Examples of the generation of disease-resistant plants using new genomic technologies

\begin{tabular}{llll}
\hline Plant host & Genome technology & \multicolumn{1}{c}{ Disease/pathogen target } & References \\
\hline Cucumber & Cas9/sgRNA & $\begin{array}{c}\text { Cucumber vein yellowing virus, Zucchini yellowing } \\
\text { virus, Papaya ring spot mosaic virus }\end{array}$ & Chandrasekaran et al. in press \\
\hline Grapefruit & Cas9/sgRNA & Citrus canker, Xanthomonas citri & Jia et al. 2016 \\
\hline Rice & TALEN & Bacterial blight, Xanthomonas oryzae pv. oryzae & Li et al. 2012 \\
\hline Tobacco & Cas9/sgRNA & $\begin{array}{l}\text { Tomato yellow leaf curl virus } \\
\text { Beet severe curly top virus }\end{array}$ & Ali et al. 2015 \\
Wi et al. 2015
\end{tabular}


outstanding painting. In other words, genomics may provide us with the complete genetic blueprint of an organism, proteomics may enable us to determine all of the proteins produced by an organism under a given set of conditions, and so forth. However, we must continually remember that we are studying bacterial pathogens that have evolved to circumvent host resistance and to cause disease on certain plant hosts. Genomic data gives us the potential to generate testable hypotheses about mechanisms and processes and regulation and orchestration of pathogenesis, but these technologies do not provide us with all of the functional knowledge that we need to truly understand and apply that knowledge to the particular task at hand, in this case, plant disease management.

In phytobacteriology, the disease triangle, which is the central paradigm of plant pathology (Stevens 1960), can be used to describe both disease management approaches and how genome-enabled approaches have or may change management of bacterial diseases of plants. If we think of the traditional disease triangle as a Venn diagram and consider how overlapping components of virulent pathogen, susceptible host, and conducive environment result in disease incidence, it becomes more clear that disruption of any of the three components is what is necessary to reduce the occurrence of disease (Fig. 3). The main goal of successful bacterial disease management is to reduce disease incidence to the point that crop production can be sustainable. As we discussed above, and summarize in Figure 3, genomic studies are enabling researchers to address each component of the disease triangle, and advances boosting disease management can come from any of these research foci.

The field of plant bacteriology is off to a great start in the first 15 years of translating genomics data into disease management strategies. Momentum is especially strong in the area of development of resistant plant hosts using novel genomic technologies, in particular the Cas9/sgRNA system. As we begin to enter the next phase of advancement of management studies spawned from genomic data, we must remember that, to ensure any likelihood of success, the field of plant bacteriology must be continually populated with researchers studying pathogen biology and studying bacterial diseases in the field and that this type of research will always be essential to take genomics from promise to practice. Why do pathogens carry a particular repertoire of type III effectors? How are these effectors deployed to suppress infection and cause disease? What drives the diversity of effector repertoire (plant host and other factors) even within pathovars? How do the other virulence systems of the pathogen play into the interaction with plant hosts that differ in susceptibility? How do all of these interactions progress in field conditions compared with in controlled greenhouse or growth-chamber conditions? What is the role of the phytobiome (the newest genomics buzzword) in influencing pathogenesis and bacterial pathogen populations in the field?

\section{FIGURE 3}

Venn diagram illustrating the plant disease triangle with bulleted points indicating how genomics research can address all three components of pathogen, host, and environment to generate knowledge and inform future sustainable disease management strategies.
- Assessment of the influence of phytobiomes on pathogenesis and on the dynamics of pathogen populations within plants, on plant surfaces, and in the soil

- Characterization of the genetic bases of pathogen adaptability to changing climatic conditions

- Evaluation of the role of micro-climates on bacterial fitness

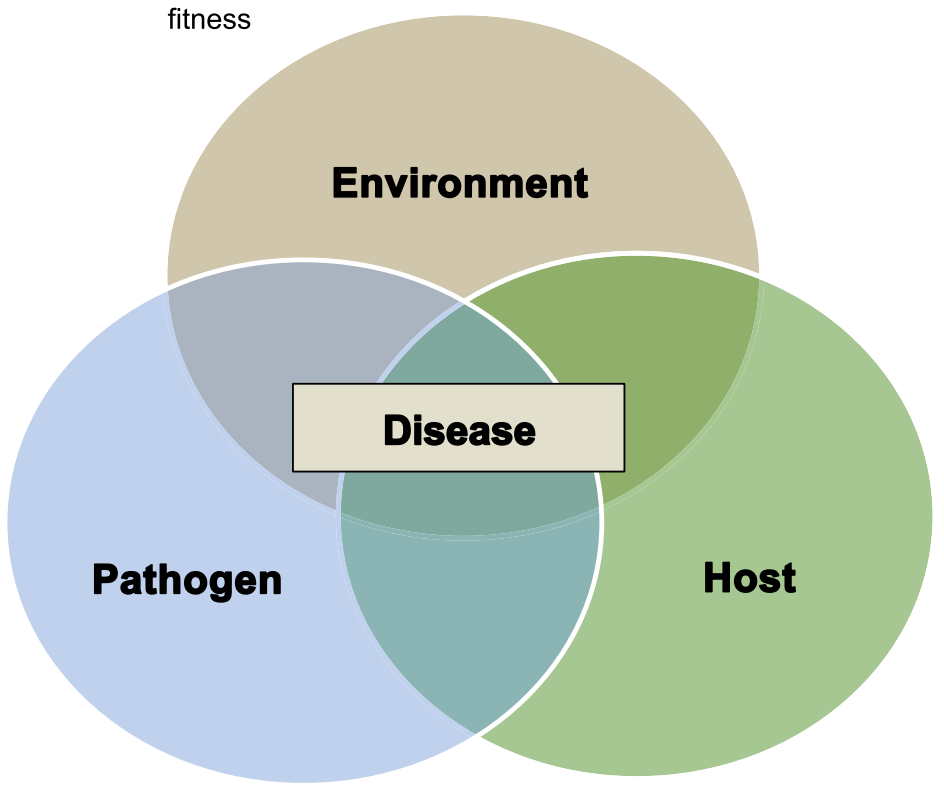

- Identification of complete and core effector repertoires

- Identification of virulence regulons

- Discovery of virulence genes in recalcitrant plant pathogens

- Discovery of novel small molecules inhibitory to pathogen virulence and regulatory functions

- Identification of resistance genes

- Genome engineering for durable resistance

- $\quad$ Genome wide marker-assisted breeding

- Genome wide screening of wild hosts as new sources of resistance

- Improvement of pathogen detection methods 
Indeed, how pathogens evolve in the field and mechanisms by which plant resistance imposes selection on pathogens remain very open questions (Arnold and Jackson 2011).

These types of mechanistic questions must be addressed to inform and enable future novel strategies of bacterial disease management, just as genomic studies informed and enabled the research developing novel management strategies. For genomics to truly drive and advance disease management, we need more pathologists "working in the trenches," taking critical research findings to the field and working on fine-tuning novel disease management mechanisms in the field and understanding how year-to-year and geographical differences in environmental conditions impact these management mechanisms. We will also need plant bacteriologists working in the extension arena that have research expertise and experience in genomics and pathogen biology as well as in applied areas to assist with grower implementation of novel bacterial disease management methods.

Understanding how pathogens react to and interact with resistant plant populations will be critical, as deployment of host resistance in agricultural settings will place novel selective pressures on pathogens. The ability of bacteria to evolve resistance to antibacterial drugs, either by mutation or gene acquisition, should serve as an overarching principle guiding all management efforts targeting bacterial plant pathogens. Introduction of a working management mechanism will not represent a success unless this mechanism is sustainable.

\section{ACKNOWLEDGMENTS}

Work in the authors' laboratories is funded by the Agriculture and Food Research Initiative competitive grant numbers 2013-5110620944 and 2015-67013-23068 (G. W. Sundin) and 2016-6701324812 (Y. Zhao), from the United States Department of Agriculture (USDA) National Institute of Food and Agriculture, Michigan State University AgBioResearch, Project GREEEN, a Michigan plant agriculture initiative at Michigan State University, the Citrus Research and Development Foundation, USDA Specialty Block Grant, and Florida Citrus Initiative.

\section{LITERATURE CITED}

Abendroth, U., Schmidtke, C., and Bonas, U. 2014. Small non-coding RNAs in plant-pathogenic Xanthomonas spp. RNA Biol. 11:457-463.

Akula, N., Trivedi, P., Han, F. Q., and Wang, N. 2012. Identification of small molecule inhibitors against SecA of Candidatus Liberibacter asiaticus by structure based design. Eur. J. Med. Chem. 54:919-924.

Akula, N., Zheng, H., Han, F. Q., and Wang, N. 2011. Discovery of novel SecA inhibitors of Candidatus Liberibacter asiaticus by structure based design. Bioorg. Med. Chem. Lett. 21:4183-4188.

Alfano, J. R., Charkowski, A. O., Debg, W. L., Badel, J. L., Petnicki-Ocwieja, T., van Dijk, K., and Collmer, A. 2000. The Pseudomonas syringae Hrp pathogenicity island has a tripartite mosaic structure composed of a cluster of type III secretion genes bounded by exchangeable effector and conserved effector loci that contribute to parasitic fitness and pathogenicity in plants. Proc. Natl. Acad. Sci. U.S.A. 97:4856-4861.

Alfano, J. R., and Collmer, A. 1997. The type III (Hrp) secretion pathway of plant pathogenic bacteria: Trafficking harpins, Avr proteins, and death. J. Bacteriol. 179:5655-5662.

Ali, Z., Abulfaraj, A., Idris, A., Ali, S., Tashkandi, M., and Mahfouz, M. M. 2015. CRISPR/Cas9-mediated viral interference in plants. Genome Biol. $16: 238$.

Ancona, V., Lee, J. H., Chatnaparat, T., Oh, J., Hong, J. I., and Zhao, Y. F. 2015. The bacterial alarmone (p)ppGpp activates the type III secretion system in Erwinia amylovora. J. Bacteriol. 197:1433-1443.

Aragón, I. M., Perez-Mendoza, D., Gallegos, M. T., and Ramos, C. 2015. The c-di-GMP phosphodiesterase BifA is involved in the virulence of bacteria from the Pseudomonas syringae complex. Mol. Plant Pathol. 16:604-615.

Arnold, D. L., and Jackson, R. W. 2011. Bacterial genomes: Evolution of pathogenicity. Curr. Opin. Plant Biol. 14:385-391.

Baltrus, D. A., Nishimura, M. T., Doughtery, K. M., Biswas, S., Mukhtar, M. S., Vicente, J., Holub, E. B., and Dangl, J. L. 2012. The molecular basis of host specialization in bean pathovars of Pseudomonas syringae. Mol. Plant-Microbe Interact. 25:877-888.

Barrangou, R., Fremaux, C., Deveau, H., Richards, M., Boyaval, P., Moineau, S., Romero, D. A., and Horvath, P. 2007. CRISPR provides acquired resistance against viruses in prokaryotes. Science 315:1709-1712.

Bell, K. S., Sebaihia, M., Pritchard, L., Holden, M. T. G., Hyman, L. J., Holeva, M. C., Thomson, N. R., Bentley, S. D., Churcher, L. J. C., Mungall, K., Atkin, R., Bason, N., Brooks, K., Chillingworth, T., Clark, K., Doggett, J., Fraser, A., Hance, Z., Hauser, H., Jagels, K., Moule, S., Norbertczak, H., Ormond, D., Price, C., Quail, M. A., Sanders, M., Walker, D., Whitehead, S., Salmond, G. P. C., Birch, P. R. J., Parkhill, J., and Toth, I. K. 2004. Genome sequence of the enterobacterial phytopathogen Erwinia carotovora subsp. atrospetica and characterization of virulence factors. Proc. Natl. Acad. Sci. U.S.A. 101:11105-11110.

Bignell, D. R. D., Seipke, R. F., Huguet-Tapia, J. C., Chambers, A. H., Parry, R. J., and Loria, R. 2010. Streptomyces scabies 87-22 contains a coronafacic acid-like biosynthetic cluster that contributes to plant-microbe interactions. Mol. Plant-Microbe Interact. 23:161-175.

Blattner, F. R., Plunkett, G., Bloch, C. A., Perna, N. T., Burland, V., Riley, M., Collado-Vides, J., Glasner, J. D., Rode, C. K., Mayhew, G. F., Gregor, J., Davis, N. W., Kirkpatrick, H. A., Goeden, M. A., Rose, D. J., Mau, B., and Shao, Y. 1997. The complete genome sequence of Escherichia coli K-12. Science 277:1453-1462.

Boch, J., Scholze, H., Schornack, S., Landgraf, A., Hahn, S., Kay, S., Lahaye, T., Nickstadt, A., and Bonas, U. 2009. Breaking the code of DNA binding specificity of TAL-type III effectors. Science 326:1509-1512.

Bonas, U., Stall, R. E., and Staskawicz, B. 1989. Genetic and structural characterization of the avirulence gene avrBs3 from Xanthomonas campestris pv. vesicatoria. Mol. Gen. Genet. 218:127-136.

Brown, E. D., and Wright, G. D. 2016. Antibacterial drug discovery in the resistance era. Nature 529:336-343.

Buell, C. R., Joardar, V., Lindeberg, M., Selengut, J., Paulsen, I. T., Gwinn, M. L., Dodson, R. J., Deboy, R. T., Durkin, A. S., Kolonay, J. F., Madupu, R., Daugherty, S., Brinkac, L., Beanan, M. J., Haft, D. H., Nelson, W. C., Davidsen, T., Zafar, N., Zhou, L. W., Liu, J., Yuan, Q. P., Khouri, H., Fedorova, N., Tran, B., Russell, D., Berry, K., Utterback, T., Van Aken, S. E., Feldblyum, T. V., D’Ascenzo, M., Deng, W. L., Ramos, A. R., Alfano, J. R., Cartinhour, S., Chatterjee, A. K., Delaney, T. P., Lazarowitz, S. G., Martin, G. B., Schneider, D. J., Tang, X. Y., Bender, C. L., White, O., Fraser, C. M., and Collmer, A. 2003. The complete genome sequence of the Arabidopsis and tomato pathogen Pseudomonas syringae pv. tomato DC3000. Proc. Natl. Acad. Sci. U.S.A. 100:10181-10186.

Bühlmann, A., Pothier, J. F., Rezzonico, F., Smits, T. H. M., Andreou, M., Boonham, N., Duffy, B., and Frey, J. E. 2013. Erwinia amylovora loopmediated isothermal amplification (LAMP) assay for rapid pathogen detection and on-site diagnosis of fire blight. J. Microbiol. Methods 92: 332-339.

Cegelski, L., Marshall, G. R., Eldridge, G. R., and Hultgren, S. J. 2008. The biology and future prospects of antivirulence therapies. Nat. Rev. Microbiol. 6:17-27.

Cermak, T., Doyle, E. L., Christian, M., Wang, L., Zhang, Y., Schmidt, C., Baller, J. A., Somia, N. V., Bogdanove, A. J., and Voytas, D. F. 2011. Efficient design and assembly of custom TALEN and other TAL effectorbased constructs for DNA targeting. Nucleic Acids Res. 39:e82.

Chandrasekaran, J., Brumin, M., Wolf, D., Leibman, D., Klap, C., Pearlsman, M., Sherman, A., Arazi, T., and Gal-On, A. Development of broad virus resistance in non-transgenic cucumber using CRISPR/Cas9 technology. Mol. Plant Pathol. In press. doi:10.1111/mpp.12375

Chang, J. H., Urbach, J. M., Law, T. F., Arnold, L. W., Hu, A., Gombar, S., Grant, S. R., Ausubel, F. M., and Dangl, J. L. 2005. A high-throughput, near-saturating screen for type III effector genes frm Pseudomonas syringae. Proc. Natl. Acad. Sci. U.S.A. 102:2549-2554.

Chatnaparat, T., Li, Z., Korban, S. S., and Zhao, Y. F. 2015. The stringent response mediated by (p)ppGpp is required for virulence of Pseudomonas syringae pv. tomato and its survival on tomato. Mol. Plant-Microbe Interact. 28:776-789.

Chatterjee, S., Killiny, N., Almeida, R. P. P., and Lindow, S. E. 2010. Role of cyclic di-GMP in Xylella fastidiosa biofilm formation, plant virulence, and insect transmission. Mol. Plant-Microbe Interact. 23:13561363.

Chen, K., and Gao, C. 2013. TALENs: Customizable molecular DNA scissors for genome engineering of plants. J. Gen. Genom. 40:271-279.

Chou, S.-H., and Galperin, M. Y. 2016. Diversity of cyclic di-GMP-binding proteins and mechanisms. J. Bacteriol. 198:32-46.

Chung, E.-H., El-Kasmi, F., He, Y., Loehr, A., and Dangl, J. L. 2014. A plant phosphoswitch platform repeatedly targeted by type III effector proteins regulates the output of both tiers of plant immune receptors. Cell Host Microbe 16:484-494. 
Cong, L., Ran, F. A., Cox, D., Lin, S., Barretto, R., Habib, N., Hsu, P. D., Wu, X., Jiang, W., Marraffini, L. A., and Zhang, F. 2013. Multiplex genome engineering using CRISPR/Cas systems. Science 339:819-823.

Cunnac, S., Lindeberg, M., and Collmer, A. 2009. Pseudomonas syringae type III secretion system effectors: Repertoires in search of functions. Curr. Opin. Microbiol. 12:53-60.

Curtin, S. J., Anderson, J. E., Starker, C. G., Baltes, N. J., Mani, D., Voytas, D. F., and Stupar, R. M. 2013. Targeted mutagenesis for functional analysis of gene duplication in legumes. Methods Mol. Biol. 1069:25-42.

de Souza, A. A., Ionescu, M., Baccari, C., da Silva, A. M., and Lindow, S. E. 2013. Phenotype overlap in Xylella fastidiosa is controlled by the cyclic diGMP phosphodiesterase Eal in response to antibiotic exposure and diffusible signal factor-mediated cell-cell signaling. Appl. Environ. Microbiol. 79:3444-3454

Deltcheva, E., Chylinski, K., Sharma, C. M., Gonzales, K., Chao, Y., Pirzada, Z. A., Eckert, M. R., Vogel, J., and Charpentier, E. 2011. CRISPR RNA maturation by trans-encoded small RNA and host factor RNase III. Nature 471:602-607.

Dequivre, M., Diel, B., Villard, C., Sismeiro, O., Durot, M., Coppee, J. Y., Nesme, X., Vial, L., and Hommais, F. 2015. Small RNA deep-sequencing analyses reveal a new regulator of virulence in Agrobacterium fabrum C58. Mol. Plant-Microbe Interact. 28:580-589.

Dow, J. M., Fouhy, Y., Lucey, J. F., and Ryan, R. P. 2006. The HD-GYP domain, cyclic di-GMP signaling, and bacterial virulence to plants. Mol. Plant-Microbe Interact. 19:1378-1384.

Doyle, E. L., Stoddard, B. L., Voytas, D. L., and Bogdanove, A. J. 2013. TAL effectors: Highly adaptable phytobacterial virulence factors and readily engineered DNA-targeting proteins. Trends Cell Biol. 23:390-398.

Duan, Y., Zhou, L. J., Hall, D. G., Li, W. B., Doddapaneni, H., Lin, H., Liu, L., Vahling, C. M., Gabriel, D. W., Williams, K. P., Dickerman, A., Sun, Y. J., and Gottwald, T. 2009. Complete genome sequence of citrus huanglongbing bacterium, 'Candidatus Liberibacter asiaticus' obtained through metagenomics. Mol. Plant-Microbe Interact. 22:1011-1020.

Edmunds, A. C., Castiblanco, L. F., Sundin, G. W., and Waters, C. M. 2013. Cyclic di-GMP modulates the disease progression of Erwinia amylovora. J. Bacteriol. 195:2155-2165.

Feirer, N., Xu, J., Allen, K. D., Koestler, B. J., Bruger, E. L., Waters, C. M., White, R. H., and Fuqua, C. 2015. A pterin-dependent signaling pathway regulates a dual function diguanylate cyclase-phosphodiesterase controlling surface attachment in Agrobacterium tumefaciens. MBio 6: e00156-15.

Fouts, D. E., Abramovitch, R. B., Alfano, J. R., Baldo, A. M., Buell, C. R., Cartinhour, S., Chatterjee, A. K., D’Ascenzo, M., Gwinn, M. L., Lazarowitz, S., Lin, N. C., Martin, G. B., Rehm, A. H., Schneider, D. J., van Dijk, K., Tang, X. Y., and Collmer, A. 2002. Genomewide identification of Pseudomonas syringae pv. tomato DC3000 promoters controlled by the HrpL alternative sigma factor. Proc. Natl. Acad. Sci. U.S.A. 99: 2275-2280.

Galán, J. E., and Collmer, A. 1999. Type III secretion machines: Bacterial devices for protein delivery into host cells. Science 284:1322-1328.

Gao, J., Wang, G., Ma, S., Xie, X., Wu, X., Zhang, X., Wu, Y., Zhao, P., and Xia, Q. 2015. CRISPR/Cas9-mediated targeted mutagenesis in Nicotiana tabacum. Plant Mol. Biol. 87:99-110.

Gartemann, K.-H., Abt, B., Bekel, T., Burger, A., Engemann, J., Flugel, M., Gaigalat, L., Goesmann, A., Grafen, I., Kalinowski, J., Kaup, O., Kirchner, O., Krause, L., Linke, B., McHardy, A., Meyer, F., Pohle, S., Ruckert, C., Schneiker, S., Zellermann, E.-M., Puhler, A., Eichenlaub, R., Kaiser, O., and Bartels, D. 2008. The genome sequence of the tomato pathogen Clavibacter michiganensis subsp. michiganensis NCPPB382 reveals a large island involved in pathogenicity. J. Bacteriol. 190:2138-2149.

Gimenez-Ibanez, S., Boter, M., Fernandez-Barbero, G., Chini, A., Rathjen, J. P., and Solano, R. 2014. The bacterial effector HopX1 targets JAZ transcriptional repressors to activate jasmonate signaling and promote infection in Arabidopsis. PLoS Biol. 12:e1001792.

Ham, J. H. 2013. Intercellular and intracellular signalling systems that globally control the expression of virulence genes in plant pathogenic bacteria. Mol. Plant Pathol. 14:308-322.

Hamilton, J. P., Hansey, C. N., Whitty, B. R., Stoffel, K., Massa, A. N., Van Deynze, A., De Jong, W. S., Douches, D. S., and Buell, C. R. 2011. Single nucleotide polymorphism discovery in elite North American potato germplasm. BMC Genomics 12:302.

Hu, Y., Zhang, J., Jia, H., Sosso, D., Li, T., Frommer, W. B., Yang, B., White, F. F., Wang, N., and Jones, J. B. 2014. Lateral organ boundaries 1 is a disease susceptibility gene for citrus bacterial canker disease. Proc. Natl. Acad. Sci. U.S.A. 111:E521-529.

Ji, X., Zhang, H., Zhang, Y., Wang, Y., and Gao, C. 2015. Establishing a CRISPR-Cas-like immune system conferring DNA virus resistance in plants. Nat. Plants 1:15144.
Jia, H., Orbovic, V., Jones, J. B., and Wang, N. 2016. Modification of the PthA4 effector binding elements in Type I CsLOB1 promoter using Cas9/ sgRNA to produce transgenic Duncan grapefruit alleviating Xcc $\Delta$ pthA4: dCsLOB1.3 infection. Plant Biotechnol. J. 14:1291-1301.

Jia, H., and Wang, N. 2014. Targeted genome editing of sweet orange using Cas9/sgRNA. PLoS One 9:e93806.

Jiang, W., Zhou, H., Bi, H., Fromm, M., Yang, B., and Weeks, D. P. 2013. Demonstration of CRISPR/Cas9/sgRNA-mediated targeted gene modification in Arabidopsis, tobacco, sorghum and rice. Nucleic Acids Res. 41: e188.

Jinek, M., Chylinski, K., Fonfara, I., Hauer, M., Doudna, J. A., and Charpentier, E. 2012. A programmable dual-RNA-guided DNA endonuclease in adaptive bacterial immunity. Science 337:816-821.

Jones, L. A., Saha, S., Collmer, A., Smart, C. D., and Lindeberg, M. 2015. Genome-assisted development of a diagnostic protocol for distinguishing high virulence Pseudomonas syringae pv. tomato strains. Plant Dis. 99: 527-534.

Kaneko, H., Kawana, T., Fukushima, E., and Suzutani, T. 2007. Tolerance of loop-mediated isothermal amplification to a culture medium and biological substances. J. Biochem. Biophys. Methods 70:499-501.

Khokhani, D., Zhang, C., Li, Y., Wang, Q., Zeng, Q., Yamazaki, A., Hutchins, W., Zhou, S. S., Chen, X., and Yang, C. H. 2013. Discovery of plant phenolic compounds that act as type III secretion system inhibitors or inducers of the fire blight pathogen, Erwinia amylovora. Appl. Environ. Microbiol. 79:5424-5436.

Kim, S. H., Qi, D., Ashfield, T., Helm, M., and Innes, R. W. 2016. Using decoys to expand the recognition specificity of a plant disease resistance protein. Science 351:684-687.

Kubota, R., Schell, M. A., Peckham, G. D., Rue, J., Alvarez, A. A., Allen, C., and Jenkins, D. M. 2011. In silico genomic subtraction guides development of highly accurate, DNA-based diagnostics for Ralstonia solanacearum race 3 biovar 2 and blood disease bacterium. J. Gen. Plant Pathol. 77: 182-193.

Lang, J. M., Hamilton, J. P., Diaz, M. C. Q., Van Sluys, M. A., Burgos, M. R. G., Cruz, C. M. V., Buell, C. R., Tisserat, N. A., and Leach, J. E. 2010. Genomics-based diagnostic marker development for Xanthomonas oryzae pv. oryzae and X. oryzae pv. oryzicola. Plant Dis. 94:311319.

Lapouge, K., Schubert, M., Allain, F. H. T., and Haas, D. 2008. Gac/Rsm signal transduction pathway of gamma-proteobacteria: From RNA recognition to regulation of social behaviour. Mol. Microbiol. 67:241253

Li, J., and Wang, N. 2014. Foliar application of biofilm formation-inhibiting compounds enhances control of citrus canker caused by Xanthomonas citri subsp. citri. Phytopathology 104:134-142.

Li, T., Liu, B., Spalding, M. H., Weeks, D. P., and Yang, B. 2012. Highefficiency TALEN-based gene editing produces disease-resistant rice. Nat. Biotechnol. 30:390-392.

Li, Y., Hutchins, W., Wu, X., Liang, C., Zhang, C., Yuan, X., Khokani, D., Chen, X., Che, Y., Wang, Q., and Yang, C.-H. 2015. Derivative of plant phenolic compound inhibits the type III secretion system of Dickeya dadantii via HrpX/HrpY two-component signal transduction and Rsm systems. Mol. Plant Pathol. 16:150-163.

Li, Y., Peng, Q., Selimi, D., Wang, Q., Charkowski, A. O., Chen, X., and Yang, C.-H. 2009. The plant phenolic compound p-coumaric acid represses gene expression in the Dickeya dadantii type III secretion system. Appl. Environ. Microbiol. 75:1223-1228.

Lin, H., Lou, B., Glynn, J. M., Doddapaneni, H., Civerolo, E. L., Chen, C., Duan, Y., Zhou, L., and Vahling, C. M. 2011. The complete genome sequence of 'Candidatus Liberibacter solanacearum', the bacterium associated with potato zebra chip disease. PLoS One 6:e19135.

Lindeberg, M., Cunnac, S., and Collmer, A. 2009. The evolution of Pseudomonas syringae host specificity and type III effector repertoires. Mol. Plant Pathol. 10:767-775

Liu, H., Coulthurst, S. J., Pritchard, L., Hedley, P. E., Ravensdale, M., Humphris, S., Burr, T., Takle, G., Brurberg, M.-B., Birch, P. R. J., Salmond, G. P. C., and Toth, I. 2008. Quorum sensing coordinates brute force and stealth modes of infection in the plant pathogen Pectobacterium atrosepticum. PLoS Pathog. 4:e1000093.

Liu, Y., Cui, Y. Y., Mukherjee, A., and Chatterjee, A. K. 1998. Characterization of a novel RNA regulator of Erwinia carotovora ssp. carotovora that controls production of extracellular enzymes and secondary metabolites. Mol. Microbiol. 29:219-234.

Lloyd, A., Plaisier, C. L., Carroll, D., and Drews, G. N. 2005. Targeted mutagenesis using zinc-finger nucleases in Arabidopsis. Proc. Natl. Acad. Sci. U.S.A. 102:2232-2237.

Ma, B., Charkowski, A. O., Glasner, J. D., and Perna, N. T. 2014. Identification of host-microbe interaction factors in the genomes of soft rot-associated pathogens 
Dickeya dadantii 3937 and Pectobacterium carotovorum WPP14 with supervised machine learning. BMC Genomics 15:508.

Ma, X., Zhang, Q., Zhu, Q., Liu, W., Chen, Y., Qiu, R., Wang, B., Yang, Z., Li, H., Lin, Y., Xie, Y., Shen, R., Chen, S., Wang, Z., Guo, J., Chen, L., Zhao, X., Dong, Z., and Liu, Y. G. 2015. A robust CRISPR/Cas9 system for convenient, high-efficiency multiplex genome editing in monocot and dicot plants. Mol. Plant 8:1274-1284.

Mali, P., Yang, L., Esvelt, K. M., Aach, J., Guell, M., DiCarlo, J. E., Norville, J. E., and Church, G. M. 2013. RNA-guided human genome engineering via Cas9. Science 339:823-826.

McCann, H. C., Rikkerink, E. H. A., Bertels, F., Fiers, M., Lu, A., Rees-George, J., Andersen, M. T., Gleave, A. P., Haubold, B., Wohlers, M. W., Guttman, D. S., Wang, P. W., Straub, C., Vanneste, J., Rainey, P. B., and Templeton, M. D. 2013. Genomic analysis of the kiwifruit pathogen Pseudomonas syringae pv. actinidiae provides insight into the origins of an emergent plant disease. PLoS Pathog. 9:e1003503.

Moscou, M. J., and Bogdanove, A. J. 2009. A simple cipher governs DNA recognition by TAL effectors. Science 326:1501.

Mucyn, T. S., Yourstone, S., Lind, A. L., Biswas, S., Nishimura, M. T., Baltrus, D. A., Cumbie, J. S., Chang, J. H., Jones, C. D., Dangl, J. L., and Grant, S. R. 2014. Variable suites of non-effector genes are co-regulated in the type III secretion virulence regulon across the Pseudomonas syringae phylogeny. PLoS Pathog. 10:e1003807.

Mukhtar, M. S., Carvunis, A. R., Dreze, M., Epple, P., Steinbrenner, J., Moore, J., Tasan, M., Galli, M., Hao, T., Nishimura, M. T., Pevzner, S. J., Donovan, S. E., Ghamsari, L., Santhanam, B., Romero, V., Poulin, M. M., Gebreab, F., Gutierrez, B. J., Tam, S., Monachello, D., Boxem, M., Harbort, C. J., McDonald, N., Gai, L. T., Chen, H. M., He, Y. J., Vandenhaute, J., Roth, F. P., Hill, D. E., Ecker, J. R., Vidal, M., Beynon, J., Braun, P., and Dangl, J. L. 2011. Independently evolved virulence effectors converge onto hubs in a plant immune system network. Science 333:596-601.

Pagliai, F. A., Gardner, C. L., Bojilova, L., Sarnegrim, A., Tamayo, C., Potts, A. H., Teplitski, M., Folimonova, S. Y., Gonzalez, C. F., and Lorca, G. L. 2014. The transcriptional activator LdtR from 'Candidatus Liberibacter asiaticus' mediates osmotic stress tolerance. PLoS Pathog. 10:e1004101.

Peer, R., Rivlin, G., Golobovitch, S., Lapidot, M., Gal-On, A., Vainstein, A., Tzfira, T., and Flaishman, M. A. 2015. Targeted mutagenesis using zincfinger nucleases in perennial fruit trees. Planta 241:941-951.

Poirot, L., Philip, B., Schiffer-Mannioui, C., Le Clerre, D., Chion-Sotinel, I., Derniame, S., Potrel, P., Bas, C., Lemaire, L., Galetto, R., Lebuhotel, C., Eyquem, J., Cheung, G. W. K., Duclert, A., Gouble, A., Arnould, S., Peggs, K., Pule, M., Scharenberg, A. M., and Smith, J. 2015. Multiplex genomeedited T-cell manuscfacturing platform for "off-the-shelf" adoptive T-cell immunotherapies. Cancer Res. 75:3853-3864.

Pritchard, L., Humphris, S., Saddler, G. S., Parkinson, N. M., Bertrand, V., Elphinstone, J. G., and Toth, I. K. 2013. Detection of phytopathogens of the genus Dickeya using a PCR primer prediction pipeline for draft bacterial genome sequences. Plant Pathol. 62:587-596.

Qian, W., Han, Z. J., Tao, J., and He, C. Z. 2008. Genome-scale mutagenesis and phenotypic characterization of two-component signal transduction systems in Xanthomonas campetris pv. campestris ATCC 33913. Mol. Plant-Microbe Interact. 21:1128-1138.

Ramalingam, S., Narayana, A., Karthikeyan, K., and Chandrasegaran, S. 2014. TALEN-mediated generation and genetic correction of disease-specific human induced pluripotent stem cells. Curr. Gene Ther. 14:461-472.

Rigano, L. A., Malamud, F., Orce, I. G., Filippone, M. P., Marano, M. R., Morais do Amaral, A., Castagnaro, A. P., and Vojnov, A. A. 2014. Rapid and sensitive detection of Candidatus Liberibacter asiaticus by loop mediated isothermal amplification combined with a lateral flow dipstick. BMC Microbiol. 14:86.

Romling, U., Galperin, M. Y., and Gomelsky, M. 2013. Cyclic di-GMP: The first 25 years of a universal bacterial second messenger. Microbiol. Mol. Biol. Rev. 77:1-52.

Ryan, R. P., An, S. Q., Allan, J. H., McCaarthy, Y., and Dow, J. M. 2015. The DSF family of cell-cell signals: An expanding class of bacterial virulence regulators. PLoS Pathog. 11:e1004986.

Sambanthamoorthy, K., Sloup, R. E., Parashar, V., Smith, J. M., Kim, E. E., Semmelhack, M. F., Neiditch, M. B., and Waters, C. M. 2012. Identification of small molecules that antagonize diguanylate cyclase enzymes to inhibit biofilm formation. Antimicrob. Agents Chemother. 56:52025211.

Schmidtke, C., Abendroth, U., Brock, J., Serrania, J., Becker, A., and Bonas, U. 2013. Small RNA sX13: A multifaceted regulator of virulence in the plant pathogen Xanthomonas. PLoS Pathog. 9:e1003626.

Schmidtke, C., Findeib, S., Sharma, C. M., Kuhfub, J., Hoffmann, S., Vogel, J., Stadler, P. F., and Bonas, U. 2012. Genome-wide transcriptome analysis of the plant pathogen Xanthomonas identifies sRNAs with putative virulence functions. Nucleic Acids Res. 40:2020-2031.
Shan, Q., Wang, Y., Li, J., and Gao, C. 2014. Genome editing in rice and wheat using the CRISPR/Cas system. Nat. Protoc. 9:2395-2410.

Showalter, H. D., and Denny, W. A. 2008. A roadmap for drug discovery and its translation to small molecule agents in clinical development for tuberculosis treatment. Tuberculosis (Edinb.):S3-17.

Shukla, V. K., Doyon, Y., Miller, J. C., DeKelver, R. C., Moehle, E. A., Worden, S. E., Mitchell, J. C., Arnold, N. L., Gopalan, S., Meng, X., Choi, V. M., Rock, J. M., Wu, Y. Y., Katibah, G. E., Zhifang, G., McCaskill, D., Simpson, M. A., Blakeslee, B., Greenwalt, S. A., Butler, H. J., Hinkley, S. J., Zhang, L., Rebar, E. J., Gregory, P. D., and Urnov, F. D. 2009. Precise genome modification in the crop species Zea mays using zinc-finger nucleases. Nature 459:437-441.

Silver, L. L. 2011. Challenges in antibacterial discovery. Clin. Microbiol. Rev. 24:71-109.

Simpson, J. G., Reinach, F. C., Arruda, P., Abreu, F. A., Acencio, M., Alvarenga, R., Alves, L. M. C., Araya, J. E., Baia, G. S., Baptista, C. S., Barros, M. H., Bonaccorsi, E. D., Bordin, S., Bové, J. M., Briones, M. R. S., Bueno, M. R. P., Camargo, A. A., Camargo, L. E. A., Carraro, D. M., Carrer, H., Colauto, N. B., Colombo, C., Costa, F. F., Costa, M. C. R., Costa-Neto, C. M., Coutinho, L. L., Cristofani, M., Dias-Neto, E., Docena, C., El-Dorry, H., Facincani, A. P., Ferreira, A. J. S., Ferreira, V. C. A., Ferro, J. A., Fraga, J. S., França, S. C., Franco, M. C., Frohme, M., Furlan, L. R., Garnier, M., Goldman, G. H., Goldman, M. H. S., Gomes, S. L., Gruber, A., Ho, P. R., Hoheisel, J. D., Junqueira, M. L., Kemper, E. L., Kitajima, J. P., Krieger, J. E., Kuramae, E. E., Laigret, F., Lambais, M. R., Leite, L. C. C., Lemos, E. G. M., Lemos, M. V. F., Lopes, S. A., Lopes, C. R., Machado, J. A., Machado, M. A., Madeira, A. M. B. N., Madeira, H. M. F., Marino, C. L., Marques, M. V., Martins, E. A. L., Martins, E. M. F., Matsukuma, A. Y., Menck, C. F. M., Miracca, E. C., Miyaki, C. Y., Monteiro-Vitorello, C. B., Moon, D. H., Nagai, M. A., Nascimento, A. L. T. O., Netto, L. E. S., Nhani, A., Nobrega, F. G., Nunes, L. R., Oliveira, M. A., de Oliveira, M. C., de Oliveira, R. C., Palmieri, D. A., Paris, A., Peixoto, B. R., Pereira, G. A. G., Pereira, H. A., Pesquero, J. B., Quaggio, R. B., Roberto, P. G., Rodrigues, V., Rosa, A. J. D., de Rosa, V. E., de Sá, R. G., Santelli, R. V., Sawasaki, H. E., da Silva, A. C. R., da Silva, A. M., da Silva, F. R., Silva, W. A., da Silveira, J. F., Silvestri, M. L. Z., Siqueira, W. J., de Souza, A. A., de Souza, A. P., Terenzi, M. F., Truffi, D., Tsai, S. M., Verjovski-Almeida, S., Vettore, A. L., Zago, M. A., Zatz, M., Meidanis, J., and Setubal, J. C. 2000. The genome sequence of the plant pathogen Xylella fastidiosa. Nature 406:151-157.

Staskawicz, B. J., Dahlbeck, D., and Keen, N. T. 1984. Cloned avirulence gene of Pseudomonas syringae pv. glycinea determines race-specific incompatibility on Glycine max (L). Merr. Proc. Natl. Acad. Sci. U.S.A. 81:60246028.

Stevens, R. B. 1960. Cultural practices in disease control. Pages 357-429 in: Plant Pathology: An Advanced Treatise. J. G. Horsfall, and A. E.Dimond, eds. Vol. 3. Academic Press, New York.

Strauß, A., and Lahaye, T. 2013. Zinc fingers, TAL effectors, or Cas9-based DNA binding proteins: What's best for targeting desired genome loci? Mol. Plant 6:1384-1387.

Streubel, J., Blücher, C., Landgraf, A., and Boch, J. 2012. TAL effector RVD specificities and efficiencies. Nat. Biotechnol. 30:593-595.

Tan, H., West, J. A., Ramsay, J. P., Monson, R. E., Griffin, J. L., Toth, I. K., and Salmond, G. P. C. 2014. Comprehensive overexpression analysis of cyclic-di-GMP signalling proteins in the phytopathogen Pectobacterium atrosepticum reveals diverse effects on motility and virulence phenotypes. Microbiology 160:1427-1439.

Tomb, J. F., White, O., Kerlavage, A. R., Clayton, R. A., Sutton, G. G., Fleischmann, R. D., Ketchum, K. A., Klenk, H. P., Gill, S., Dougherty, B. A., Nelson, K., Quackenbush, J., Zhou, L. X., Kirkness, E. F., Peterson, S., Loftus, B., Richardson, D., Dodson, R., Khalak, H. G., Glodek, A., McKenney, K., Fitzgerald, L. M., Lee, N., Adams, M. D., Hickey, E. K., Berg, D. E., Gocayne, J. D., Utterback, T. R., Peterson, J. D., Kelley, J. M., Cotton, M. D., Weldman, J. M., Fujii, C., Bowman, C., Watthey, L., Whalin, E., Hayes, W. S., Borodovsky, M., Karp, P. D., Smith, H. O., Fraser, C. M., and Venter, J. C. 1997. The complete genome sequence of the gastric pathogen Helicobacter pylori. Nature 388:539-547.

Townsend, J. A., Wright, D. A., Winfrey, R. J., Fu, F., Maeder, M. L., Joung, J. K., and Voytas, D. F. 2009. High-frequency modification of plant genes using engineered zinc-finger nucleases. Nature 459:442-445.

Urnov, F. D., Rebar, E. J., Holmes, M. C., Zhang, H. S., and Gregory, P. D. 2010. Genome editing with engineered zinc finger nucleases. Nature 11: 636-646.

Vogel, J., and Luisi, B. F. 2011. Hfq and its constellation of RNA. Nat. Rev. Microbiol. 9:578-589.

Wang, Y., Cheng, X., Shan, Q., Zhang, Y., Liu, J., Gao, C., and Qiu, J. L. 2014. Simultaneous editing of three homoeoalleles in hexaploid bread wheat confers heritable resistance to powdery mildew. Nat. Biotechnol. 32: 947-951. 
Waters, L. S., and Storz, G. 2009. Regulatory RNAs in bacteria. Cell 136: 615-628.

Wei, H.-L., Chakravarthy, S., Mathieu, J., Helmann, T. C., Stodghill, P., Swingle, B., Martin, G. B., and Collmer, A. 2015. Pseudomonas syringae pv. tomato DC3000 type III secretion effector polymutants reveal an interplay betweem HopAD1 and AvrPtoB. Cell Host Microbe 17:752-762.

Wiedenheft, B., Sternberg, S. H., and Doudna, J. A. 2012. RNA-guided genetic silencing systems in bacteria and archaea. Nature 482:331-338.

Wilms, I., Overloper, A., Nowrousian, M., Sharma, C. M., and Naberhaus, F. 2012. Deep sequencing uncovers numerous small RNAs on all four replicons of the plant pathogen Agrobacterium tumefaciens. RNA Biol. 9:446-457.

Wright, D. A., Li, T., Yang, B., and Spalding, M. H. 2014. TALEN-mediated genome editing: Prospects and perspectives. Biochem. J. 462:15-24.

Xiao, Y. X., and Hutcheson, S. W. 1994. A single promoter sequence recognized by a newly identified alternate sigma factor directs expression of pathogenicity and host-range determinants in Pseudomonas syringae. J. Bacteriol. 176:3089-3091.

Yang, F., Korban, S. S., Pusey, L., Elofsson, M., Sundin, G. W., and Zhao, Y. F. 2014a. Small molecule inhibitors suppress expression of both type III secretion and amylovoran biosynthesis genes in Erwinia amylovora. Mol. Plant Pathol. 15:44-57.

Yang, F. H., Tian, F., Chen, H. M., Hutchins, W., Yang, C.-H., and He, C. Y. 2015. The Xanthomonas oryzae pv. oryzae PilZ domain proteins function differentially in cyclic di-GMP binding and regulation of virulence and motility. Appl. Environ. Microbiol. 81:4358-4367.

Yang, F. H., Tian, F., Li, X., Fan, S., Chen, H., Wu, M., Yang, C.-H., and He, C. Y. 2014b. The degenerate EAL-GGDEF domain protein Filp functions as a cyclic di-GMP receptor and specifically interacts with the PilZ-domain protein PXO_02715 to regulate virulence in Xanthomonas oryzae pv. oryzae. Mol. Plant-Microbe Interact. 27:578-589.

Yang, S., Peng, Q., Zhang, Q., Yi, X., Choi, C. J., Reedy, R. M., Charkowski, A. O., and Yang, C.-H. 2008. Dynamic regulation of GacA in type III secretion, pectinase gene expression, pellicle formation, and pathogenicity of Dickeya dadantii (Erwinia chrysanthemi 3937). Mol. Plant-Microbe Interact. 21:133-142.

Yuan, X., Khokhani, D., Wu, X. G., Yang, F. H., Biener, G., Koestler, B. J., Raicu, V., He, C. Y., Waters, C. M., Sundin, G. W., Tian, F., and Yang, C.-H. 2015. Cross-talk between a regulatory small RNA, cyclic di-GMP signaling and flagellar regulator FlhDC for virulence and bacterial behaviours. Environ. Microbiol. 17:4745-4763.

Zeng, Q., McNally, R. R., and Sundin, G. W. 2013. Global small RNA chaperon Hfq and regulatory small RNAs are important virulence regulators in Erwinia amylovora. J. Bacteriol. 195:1706-1717.

Zeng, Q., and Sundin, G. W. 2014. Genome-wide identification of Hfqregulated small RNAs in the fire blight pathogen Erwinia amylovora discovered small RNAs with virulence regulatory function. BMC Genomics 15:414.

Zhang, F., Maeder, M. L., Unger-Wallace, E., Hoshaw, J. P., Reyon, D., Christian, M., Li, X., Pierick, C. J., Dobbs, D., Peterson, T., Joung, J. K., and Voytas, D. F. 2010. High frequency targeted mutagenesis in Arabidopsis thaliana using zinc finger nucleases. Proc. Natl. Acad. Sci. U.S.A. 107:12028-12033.

Zhang, Y., Zhang, F., Li, X., Baller, J. A., Qi, Y., Starker, C. G., Bogdanove, A. J., and Voytas, D. F. 2013. Transcription activator-like effector nucleases enable efficient plant genome engineering. Plant Physiol. 161:20-27.

Zhao, Y., Wang, D., Nakka, S., Sundin, G. W., and Korban, S. S. 2009. Systems level analysis of two-component signal transaduction systems in Erwinia amylovora: Role in virulence, regulation of amylovoran biosynthesis and swarming motility. BMC Genomics 10:245.

Zwiesler-Vollick, J., Plovanich-Jones, A. E., Nomura, K., Bandyopadhyay, S., Joardar, V., Kunkel, B. N., and He, S.-Y. 2002. Identification of novel hrp-regulated genes through functional genomic analysis of the Pseudomonas syringae pv. tomato DC3000 genome. Mol. Microbiol. 45:1207-1218. 